HAKAN SARI

Necmettin Erbakan University, Turkey

DOI: $10.13166 / J M S / 112280$ JOURNAL OF MODERN

hakansari@gmail.com

ORCID: 0000-0003-4528-8936

SCIENCE TOM 3/42/2019, S. $57-81$

Hatice GÖKDAĞ

Necmettin Erbakan University, Turkey

gokdaghatice@hotmail.com

ORCID: 0000-0003-3044-0675

HASAN KIZILKAYA

Karamanoğlu Mehmetbey University, Turkey

hasankizilkaya35@gmail.com

ORCID: 0000-0002-2144-3834

\title{
Evaluating Teachers' Opinions on Learning Difficulties of Stuttering Primary STUdents In Terms of Terms of First LITERACY
}

\begin{abstract}
Objectives

In this study, researchers aimed to (1) investigate how stuttering affects the learning process of first reading and writing, and (2) reveal the problems encountered by children with stuttering during the first literacy process and (3) shed light on further research in this area.

Material and methods

The research is a descriptive study to determine the problems that students with stuttering have experienced in the process of learning first literacy skills. In this study, semi-structured interviewing methods were chosen from the types of interviews included in the qualitative research methods in order to evaluate the problems encountered by the stuttering students in the process of learning literacy skills in a more in-depth manner in terms of their opinions, and experiences.

Results

The data obtained from semi-structured interviews and findings were obtained by analyzing by content analysis technique. During the interview, eight questions were asked to the participant.
\end{abstract}




\section{Conclusions}

When the research findings are examined, it is seen that students with stuttering have some difficulties in reading, writing, and hearing voice and syllable, while there is not a significant difference between them in reading and writing skills of voice, syllable and words in the process of first reading and writing. Teacher's opinion revealed that stuttering students were particularly had more problems with the words or syllable starting with a strong consonant.

KEYwORDs: Stuttering, Teaching Initial Reading and Writing Skills, Children who Need Special Education, Special Educational Needs in Primary Schools, First Literacy

\section{INTRODUCTION}

Stuttering disorder is the most common disorder of speech disorders (Turan, 2016). The difficulty in producing the voices when they speak is that they cannot start to talk, startle, pause, lengthen certain voices, burst and repeat a word or syllable. In addition to these, there are also a number of hand-arm, face, body movements accompanying the talk, deviation in rhythm and fluency of talking (Özsoy, Özyürek ve Eripek, 1998; Onslow, Ross ve Pockman,2001; Dreizehnter, 2009).

Stuttering causes the repetition of voices and words to pause, to lengthen voices, to live a block while speaking, to avoid some voices or spirits, and to affect the whole of speaking, as opposed to other speech impairments (Sandrieser and Sneider, 2008). Individuals with stuttering feel anxiety towards speaking as they deal with speech impairments such as interruption of speaking, breakup of words, repetition and extension of voices (Turan, 2016).

There are many definitions of stuttering. Guitar (2006) describes stuttering as communication impairment that disturbs the flow of speech and smoothness. It is defined as stuttering, voice and syllable repetition, lengthening of voices, annotations, fragmentation of words, audible or silent gaps, and vocalizations in the Static Strain Diagnosis and Statistics Handbook (2005) (Diagnostic and Statistical Manual of Mental Disorders "DSM- (Ozturk, 1994; Karacan, 2000). In addition, there is at least one of the following: tortuous speech, excessive physical tension, and repeated syllables of the words. According to Bloodstein (1995), stuttering is defined as the 
division of speech flow or rhythm into gaps or certain discontinuities. Fışıloğlu and Ungan (1992) describe stuttering in the form of extreme difficulties in the planning phase and production of speech, and intermittent cuts in the continuity of speaking. It has also been emphasized that stuttering may be accompanied by stinging, sometimes negative emotions such as excitement, distress, fear, nervousness, which are often described as interruptions in the form of repetitive, recognizable but uncontrollable repeats and extensions of sounds and syllables involving inaudible, audible or inaudible (Perkins, 1990). It has also been emphasized that stuttering may be accompanied by stinging, sometimes negative emotions such as excitement, distress, fear, nervousness, which are often described as interruptions in the form of repetitive, recognizable but uncontrollable repeats and extensions of sounds and syllables involving inaudible, audible or inaudible (Perkins, 1990). Ozturk (1994) and Pamir (1985) explained stuttering as repetition of voice, syllable and words, an extension, a pause in speech fluency and a speech disorder that manifested itself by some body movements. The severity of the disorder varies depending on the situation in which the person is present, especially in the case of trials. Also, there is usually no stuttering while singing or reading poetry. Repetitive body movements such as shaking the head, blinking the eyes may accompany the talk when the disorder is intense (İnceer and Kocadere, 1999; Öztürk, 1994).

Stuttering is not just a fluency disorder in speech. The psychological state, personality traits and attitudes that accompany uncontrollable conversations and non-fluent speaking during the conversation also have an effect on the individual (Madanoğlu, 2005). From the definitions made, individuals who are experiencing stuttering problems should show some criteria in order to be recognized as stuttering. These criteria are expressed in terms of:

I. Disorder in the flow of speech and timing pattern, which becomes evident by the frequent occurrence of one or more of the following features, is described as stuttering criteria in DSM IV (2005):

1) Recognition of audio / syllable repeat,

2) Sound extensions are frequently encountered,

3) Being a fictitious, 
4) The disintegration of words,

5) Audible or silent blocks (interrupts filled in or not filled in during the speech),

6) Talking on the roundabout (the use of other words to substitute these words to avoid problematic words),

7) Excessive physical tension in words,

8) The monosyllable word is restricted to the appearance of repeats.

II. Speech fluency disorder effects school success, professional success, or social communication.

III. Speaking difficulties with speech, motor, sensory impairment or environmental deprivation are often found to be much higher than those accompanying them (Baumgartner, 1997; Fiedler and Standop, 1994).

Although the causes of stuttering have not yet been proven, genetic features, to be a learned behavior, psychological factors, or a combination of many factors are among the most common causes of speech disorders in children (Maviş, 2005). The problem of stuttering in communication has been a subject of research for many years and various researches have been carried out on phonological features, language development, other disorders accompanied by stuttering, physiological and acoustical properties of staples and researches on this subject continues (Natke, 2005).

According to some research results (Hansen and Iven, 2002; Anderson and Conture, 2000), the results of language tests on children are examined and it is seen that children who are stuttering or talking less fluent than children who are normally speaking, have lower linguistic skills. From the results of these studies it is emphasized that there is a strong relation between stuttering and language functions. According to ASHA (2004) (American Speech Language Hearing Association, 2004), each individual is occasionally stutter in conversation. However, the type of stuttering that the stutterer has shown is quite different from that of a normal individual (Williams, 2004). It also affects the emotional and social development of the stuttering individual, causing negative behaviors such as hesitation, jealousy, insecurity, mental and social incompatibility (Bakırcıŏglu, 2002). 
In some studies, done in the United States, about the frequency and prevalence of stuttering, it has been reported in about $1 \%$ of the total population (Bloodstein, 1995). On the other hand, 5\% of all children are stuttering in a fraction of their lives, but $80 \%$ of childhood stuttering disappears spontaneously. $5 \%$ of school-age children have speech impairment and stuttering is $0.8 \%$ among speech disorders (Brayn and Brayn, 1982).

Belgin and Derinsu (1990) have explained that the age at onset of stuttering is seen in about $90 \%$ of cases before the age of 6 , and at most between the ages of 2 and 4 years. These ages are the ages at which speech is earned and a temporary stuttering called "physiological stuttering" can be seen in this period. It usually begins with the appearance of repetitions with extensions. While the child is talking, he can pause and repeat, but he is unaware of it. This period can be completed with a fluent speech towards the ages of 7 or 8 (Özsoy, 1982, Andrews et al., 1983, Öztürk, 1994). In some studies, it has been reported that stuttering is seen more frequently in males than in females (Van Riper, 1972, Öztürk, 1994; Wingate, 2002). Research shows that the ratio of male to female changes by $1 / 2,1 / 3,1 / 5,1 / 10$ (Yörükoğlu and Akyıld1z, 1971, Özsoy, 1982). Andrews et al. (1983) stated that these ratios increased with age.

The inability to reach a common judgment and agreement on the definition and reasons for the stuttering influenced the emergence of many theories about the causes of stuttering (Shipley and McAfee, 2004). Despite the wide range of theories related to the reasons for the stuttering, there is no clear data on the cause of the stuttering (Bloodstein and Ratner, 2008). The theories put forward for the reason of stuttering show diversity according to popular trends of thought, philosophy and science which are popular at that time. In fact, the first theories of stuttering are based on ancient Greece. According to these theories stems from the idea that stuttering originated from the language foundation. A review of the emerging theories of the causes of stuttering in the nineteenth century suggests that stuttering is based on differences in speech organs (Büchel and Sommer, 2004). Many assumptions about the causes of stuttering can be gathered under structural or physiological theories, psychological theories, learning and conditioning theories. 
Structural theories suggest that individuals with stuttering have a problem in the coordination of biochemical, brain anatomy, or speech muscles. According to those who advocate this view, the size of the larynx, left-handedness or forced left-handed use is an important reason for stuttering (Yairi and Ambrose, 2005). Shapiro (1999) suggests that the structural factors involved in genetic predisposition and left-hand dominance are prone to stammer as factors. In addition, timing errors for fast speech, insufficient capacity for sensor-motor conversion, abnormal hemispheric localization for speech and language can be observed (Shapiro, 1999).

Another theory, psychological theory, suggests that stuttering is a neurotic symptom or an indication of phobia. These manifestations originate from unconscious needs and internal conflicts (Owens et al., 2003). For example, Manning (2001) stuttering is a neurosis according to Stressed Needs, an approach based on Freud's Theory. Stuttering arises as a result of suppressed, neurotic and unconscious contradictions. Stuttering is a symptom of this plague. These theories suggest that stuttering is a symptom of something else beyond seen and sensed. According to these theorists there are profound emotional difficulties which are called "contradictions" in early childhood. These contradictions are unconscious and therefore unattainable and unsolvable (Yairi and Ambrose, 2005).

According to learning theories, stuttering is expressed as a learned behavior. Stuttering develops by reinforcement of the child's fluency in situations such as paying more attention to fluency by the environment (Tanner, 2003). From a behavioral point of view, Bleumel stated that there may be a stimulus-response relationship in stuttering. In other words, stuttering is a behavior learned by reinforcement and punishment, and it is a result of the reactions given to the interactions between the behavior of the individual and the environment in which the behavior is observed (Ward, 2006).

In recent years, various models have been developed with the assumption that stuttering may have more than one cause. According to the Demand and Capacity model, the fluency of most children develops at the same rate as demand and the fluency increases. In some children, 
the fluency of speech does not develop and the fluency demands exceed the capacity of the child. In this case, fluent speech becomes distorted and unstable (Starkweather, 1993). It is aimed to examine the interaction of environmental and genetic elements with each other, especially in the development of stuttering. Starkweather also explains why claims and capacities theory and stuttering (Kehoe, 1999; Yaruss, 1999).

When the literature is examined, it is seen that the research on the relationship among stuttering and success of the intelligence and academic courses is very limited. A study conducted abroad by McDowell (1928) showed that there was no significant difference between StanfordBinet Results and Academic Achievement levels for stutterers and nonstutterers. Another study that was conducted in a similar way to this study is the work performed by Andrews, Craig, Feyer, Hoddinott, Hoiwe and Neilson (1983). According to this research result, there is no significant difference between intelligence levels of stuttering and fluent children. When we look at domestic studies, it is seen that studies that study stuttering and academic success relation with stuttering are very limited. Abali, Kınalı and Beşikçi (2004) have conducted the WISC-R-II test with the participant in a study conducted with thirty-five children aged six to eighteen who were diagnosed with stuttering, and concluded that there was no significant difference between Verbal IQ and Performance IQ according to the test result. According to the results of the study, there is no significant relationship between WISC-R-II test results and stuttering severity. Pinarcik (2013) found that students who had stuttering problems had no significant problems in academic and school achievement, but their success in verbal lessons was lower than in other courses, in a study of 6-8 year olds who were assessing the difficulties they faced psycho-social and academic. Despite the limited number of studies that investigate the level of intelligence and academic achievement of children with stuttering, the research that examines the process of learning stuttering children's first literacy is very limited. In this study, researchers aimed to (1) investigate how stuttering affects the learning process of first reading and writing, and (2) reveal the problems encountered by children with stuttering during the first literacy process and (2) shed light on further research in this area. 


\section{Method}

This section provides information on the design, study group, data collection tools and data analysis of this research.

\section{Study Design}

The research is a descriptive study to determine the problems that students with stuttering have experienced in the process of learning first literacy skills. In this study, semi-structured interviewing methods were chosen from the types of interviews included in the qualitative research methods in order to evaluate the problems encountered by the stuttering students in the process of learning literacy skills in a more in-depth manner in terms of their opinions, and experiences. The main purpose of the qualitative researches is to reveal in depth the feelings and thoughts about the research problem of the study group participating in the research (Ylldırım and Şimşek, 2006) .In semi-structured interview technique, researchers prepared the interview protocol which includes the questions that the researchers wanted to ask in advance. The researchers are able to direct the answer in more detail because the interviewer may influence the flow of the interview with different side or sub questions depending on the progress of the interviewee. As reported in Ylldırım and Şimşek (2004), semi-structured interview technique has been chosen because of its great convenience to the researcher because it provides more systematic and comparable information because the interviewer is based on the preprepared interview protocol.

\section{Study Group}

The study group of the study consists of class teachers who worked in Konya Provincial Directorate of National Education. The participant group of twenty-eight elementary school teachers who worked at the primary schools in the provincial centers of the Konya Provincial Directorate of Education and who had at least five years of teaching experience and who worked with at least two stuttering students in their professional lives. The teachers participating in the research are informed that they do not have to participate in the research. Participants in this study agreed to participate voluntarily in the search. 
Table 1

Participants

\begin{tabular}{|c|c|c|}
\hline \multirow{2}{*}{ Central Districts } & \multicolumn{2}{|c|}{ Teachers } \\
\cline { 2 - 3 } & F & M \\
\hline Meram & 6 & 3 \\
\hline Selçuklu & 4 & 3 \\
\hline Karatay & 5 & 4 \\
\hline
\end{tabular}

F: Female

M: Male

\section{Data Collection Tools}

In this study, data were collected through Semi-structured Interview Method. The Semi-structured Interview Form developed by the researcher was applied. The interview forms were reviewed by three experts with experience in qualitative research, and the expressions were rearranged in line with the opinions and feedback received from the experts. The forms in which the edited and amended statements take place have been sent back to the experts for review. The items shaped in the light of the arrangements made as follows:

1) For the pilot study, the questions in the Interview Forms were asked to three teachers, and the unexplained expressions were corrected and asked again.

2) The interview questions were reviewed by three experienced specialists in qualitative researches in order to bring the unrecognized items into a more understandable form after the pilot study.

3) Semi-structured Interview Forms given in the final format for the application to be used in the research.

Teachers involved in the interview are asked:

1) Are the children with stuttering experiencing difficulties in voicing their first vocabulary while learning to read and write?

2) Do they have difficulty in correct writing the voices?

3) Do they have difficulty reading syllables correctly?

4) Do they have difficulty in correct writing syllables? 
5) Do they have difficulty in producing and reading new words?

6) Do they have difficulty in writing new words?

7) Do they have difficulty in understanding what they read and not expressing what they understand?

8) Do you observe differences in the duration of the transition of the students with stuttering to reading and writing and the transition of the other students to reading and writing?

\section{Analysis}

Following the completion of the interviews, the voice recordings of the interviews made with the participants were analyzed, the data in the interview form was made in writing, and the interview coding key was created by evaluating the records one by one. The transcripts of the interviews were read individually and carefully and analyzed with the help of the 'Content Analysis' technique. The themes emerging from the content analysis were presented in the main and sub titles presented in the 'findings' section. One of the interviews was selected and evaluated by one of the researchers and one of the experts independently from each other according to the interview coding key. In order to determine its consistency, the coding key was given the final shape by comparing the markings made by the researcher and the expert in the coding key and making the necessary changes. For each participant participating in the interview, the coding keys filled by the investigator and the expert and they were compared to ensure consistency. In the computation of the reliability of the studies, the percentages of correspondence between the encodings, calculated by the investigator and the field investigator separately, were calculated (percent agreement $=$ agreement quantity X100 / match + incompatibility). The percentage of complaints in the study was $86 \%$.

\section{Findings}

This section contains findings from research data. The data obtained from semi-structured interviews and findings were obtained by analyzing by content analysis technique. During the interview, eight questions were asked to the participant.

\section{Are the children with stuttering experiencing difficulties in voicing}




\title{
their first vocabulary while learning to read and write?
}

When teachers participating in this study were asked about the difficulties they experienced in their vocalizations, the majority (19: 76\%) of the teachers participating in the study stated that children had difficulty in vocalization studies.

\begin{abstract}
"Yes, the children with stuttering have difficulty in voicing their voices we are working on during their literacy work" (Teacher, 3 ).

'Generally, I think it is challenging him as he thinks that he cannot voice correctly because he stutters, I think he actually learns the voice' (Teacher, 7).
\end{abstract}

The four teachers who participated in the research indicated that children with stuttering had no difficulties during phonation studies and they had developed at the same level as other students in the class during phonation.

'No, I do not think my student with stuttering is having difficulty in vocalizing' (Teacher, 19).

'I did not notice a difference between the other children' (Teacher, 20).

The two teachers who participated in the research stated that the stuttering students had difficulty in the vocalization studies partially, especially when they were voiced to say the words they have difficulty to say. Stuttering students pronounce the words incorrectly to avoid stuttering when they hear a difficult voice.

'My stutter student is having difficulty in saying some voices in the study of his pronunciation' (Teacher, 5).

'I realized that they were having difficulties in the strong consonants' (Teacher, 23).

\section{Students' Difficulties in Writing Correct Words}

More than half of the teachers (16:65\%) reported that their voices did not have any extra difficulty in writing their voices, and that they were progressing at the same level as other children in correct writing of the voices spoken in their literacy work.

'My stutter student did not have any difficulty in writing the voice when it was said,' (Teacher, 8). 
'No, he did not have a problem' (Teacher, 2).

Approximately one-third of the interviewed teachers (9: 36\%) stated that students with stuttering had problems from time to time in the correct writing of their voices. When asked which questions they are experiencing more difficulties, they gave the answer that they had problems in writing especially the strong consonant voices.

'My stutter student had problems especially in the strong consonant letters' (Teacher, 11).

'They have more difficulty in consonant voices' (Teacher, 22).

\section{Students' Difficulties in the Reading Process}

Nearly all of the teachers who participated in the study (23: 92\%) stated that the students with stuttering had difficulty in reading the syllables. According to the findings obtained from teacher opinions, the degree of difficulty in reading efficiency of stuttering students is increasing especially when the working voice is given at the beginning of the syllable.

'The student with the stuttering has difficulty reading the syllables' (Teacher, 16).

'The student with the stuttering has difficulty reading the syllable starting syllables' (Teacher, 8).

'The student with the stuttering has difficulty in distinguishing the syllables '(Teacher, 25).

Two teachers who participated in the study stated that stuttering students had difficulty in correct reading of the syllables during the first literacy phase. Five of the teachers who participated in the research stated that the stuttering children experienced some difficulty during their syllables work.

It's not always. When they are excited, it is difficult to read for them '(Teacher, 11).

'It is difficult for stutters to read $p, t, t, k, s, s$ at the beginning when it separates the syllable.' (Teacher, 20).

'He is having difficulties with the syllables starting with strong consonants,' (Teacher, 7). 


\section{Difficulties Students Face in Writing the Syllables}

Nearly half (12: $48 \%)$ of the teachers who participated in the study stated that stuttering children did not have difficulties due to stuttering in correct writing. Stuttering does not have a negative effect on the process of learning to write the syllables. These students also developed in a similar way to other students.

'The stutter student was very successful in correct writing syllables' (Teacher, 3).

I did not see any difference between the other children in writing the grades' (Teacher, 8).

'He progressed at the same level as other children in the class' (Teacher, 17).

More than half (13:52\%) of the teachers participating in the study stated that the stuttering students were partially challenged in correct writing. Especially when they were raised to the board, they stated that they had difficulties in writing the syllable when they were experiencing intense excitement, and also that they had more difficulty in writing the syllables starting with a strong consonant. Anxiety and excitement that students experience makes it difficult for them to react correctly.

'Cannot write when he is excited' (Teacher, 1).

'Syllables that starts with a strong consonant are sometimes difficult for him in writing' (Teacher, 19).

'Writes better when doing group work, it is difficult to write on the board' (Teacher, 6).

\section{Difficulties of Students Compiling and Reading New Words}

More than half $(17: 68 \%)$ of the teachers participating reported that stuttering children had difficulty in reading and producing new words. Children are more likely to stutter when they encounter a new word.

'Stutter more when they are reading the new words ' (Teacher, 5).

'When it comes to reading the vocabulary aloud, they have difficulty' (Teacher, 3). 
A third (8: $32 \%)$ of the teachers who participated in the study stated that stuttering children did not experienced extreme difficulty in reading new words.

'When I give a new word, there is an extra difficulty' (Teacher, 14).

'He stutters but is not different from other times' (Teacher, 22). 'Absolutely not having difficulty' (Teacher, 20).

\section{Difficulties in Producing and Writing New Words}

About half of the teachers (10: 40\%) questioned whether children with stuttering had difficulties in producing and writing new words and they reported that children with stuttering had some difficulty in producing and writing new words. While working individually, teachers stated that stuttering students were more successful and they had difficulties in writing new words when they were assigned to the classroom, or when they were raised in the classroom. This shows that anxiety and the lack of self-esteem that students experience due to stuttering has a negative effect on achieving the desired success rather than academic difficulties.

'There is no problem when he writes in his notebook, but the success he has shown on the board changes slightly' (Teacher, 1).

More than half of those participating in the study (15: 60\%) stated that children with stuttering had the same level of progress with the class as new words experienced and did not have different difficulties from other children during the writing process.

'Sometimes he has difficulties, but I do not think it's due to stuttering.' (Teacher, 2).

'There is no significant difference with other children, almost the same levels' (Teacher, 25).

\section{Difficulties Encountered in Reading}

Teachers who participated in the study questioned whether stuttering pupils had difficulty in understanding what they read, and some of them (4: $16 \%$ ) stated that they sometimes had difficulty. They also expressed that their understanding skills vary according to the severity of the stuttering, and also that the words and phrases in the text they read have changed their understanding skills when they are long. 
"My stuttering student is excited and stutters more when it comes to reading aloud in class. Then it becomes difficult to understand too '(Teacher, 11).

'Their understanding depends on the level of stuttering ' (Teacher, 6).

'Words and phrases in the text are more difficult for them when they are long' (Teacher, 17).

About one third of the teachers (7: 28\%) who participated in the study reported that stuttering students had difficulty in understanding what they read. When students read aloud, the level of understanding is affected negatively because they focus on stuttering rather than the text. The level of expression of what they understand about the text being read is usually in the form of a single word or a sentence consisting of two words.

'He cannot draw his attention to understand because he stutters; has difficulty in understanding what he is reading' (Teacher, 25).

'Yes, he has difficulty in understanding what he reads, cannot focus on the text' (Teacher, 18).

'They are not able to focus on what they read exactly because they repeat voice and syllable' (Teacher, 14).

The majority of the teachers who participated in the research (14: 56\%) stated that students had no difficulty in understanding what they read due to stuttering.

'While he is reading, he repeats words and syllable, but he has no trouble in understanding' (Teacher, 3).

'No, there is no problem of understanding. But he has difficulty in expressing what he understands' (Teacher, 5).

'He understands what he reads, but he usually expresses it in one word' (Teacher, 15)

\section{Differences in Stuttering Students and Other Students in Transition to Reading and Writing}

When teachers who participated in the research were directed to the question of whether students with stuttering had a difference in reading- 
writing compared to other students, most teachers (14: 56\%) reported that they did not observe any difference in reading-writing compared to other students but stuttering students had problems with voices, speaking the syllables, and learning voices.

'No, I did not observe a difference in learning' (Teacher, 8).

'My stutter student was one of the first students who read and write in class' (Teacher, 10).

'He knew to read and write when he came' (Teacher, 19).

About half (11: 44\%) of the teachers who participated in the study stated that the stuttering students' reading-writing transition period was slightly different from the other students. They stated that stuttering students had a little delay compared to other students in the process of learning to read and write because they were hesitant to participate in class activities and were not actively participating in the lessons.

'Stutter students are constantly afraid to speak and learn late because they do not want to speak' (Teacher, 4).

'It happens, of course. They are more abstentious, have difficulties in expressing themselves' (Teacher, 11).

\section{Discussion}

When the research findings are examined, it is seen that students with stuttering have some difficulties in reading, writing, and hearing voice and syllable, while there is not a significant difference between them in reading and writing skills of voice, syllable and words in the process of first reading and writing. Teacher's opinion revealed that stuttering students were particularly had more problems with the words or syllable starting with a strong consonant. The problem that pupils experience during their reading studies is not an academic problem in learning the sounds, syllables and words but it is caused by the high level of anxiety due to the stuttering problem of the students, as they cannot feel comfortable, and they are afraid and worried that the other students in the class will have negative attitudes 
when they stutter during reading. Thinking about the students' stuttering in their reading studies or their peers' negative attitude when they stutter rise their exclusion, intimacy, fears of being mocked and anxiety levels. When the literature is examined, it is seen that there are similar research results. Fletcher (1974) defines stuttering as an abnormal social response in his work. He emphasized that the main factors cause abnormal social behaviors are the resulting emotional states of certain experiences such as fear, horror, anxiety, and inferiority (Wischner, 1992). The degree of discomfort experienced by stuttering increases, when the child is in fear, tension, pressure, shame, and avoidance. This situation affects the development of the child's self-esteem in a detrimental way. Therefore, stuttering is not only a speech problem, but it can also affect an individual's self-perception process and emotional reactions. So it can be said that stuttering may decrease in a great deal if the individuals with stuttering dominate the involuntary emotional reactions.

When research findings are examined, it is seen that stuttering student has more intense stress and excitement when he / she is assigned in the classroom and therefore he / she increases stuttering severity and he / she has more difficulty in reading. In cases where he / she should speak in class, stuttering expectancy increases the level of anxiety, so, stuttering increases as well. In this vicious circle, the student's self-confidence development is negatively affected. This causes the child to withdraw himself more especially in verbal lessons and to reduce his participation in the lessons. The stuttering students, especially in verbal classes like language, withdraw themselves due to stuttering and not participating in activities negatively affects the success levels of them from these lessons. There are studies supporting this result when the literature is reviewed. Sarı and Gökdağ (2017) found that students who had problems with stuttering did not have a significant problem in academic lectures but that their success rates in verbal lectures and activities were less than other courses and activities because of stuttering.

Stuttering students often try to hide their speech problems by being silent, avoiding difficult words or pretending they do not know the answer when there is a need to speak. For this reason, stuttering for teachers is not easily recognized. These avoidance behaviors mostly explained by teachers as they are badly prepared, dreamy, lazy, shy, incompetent, unsuccessful, and 
so on. Therefore, it is important that teachers should be able to determine the cause of avoidance behaviors in children, especially those who exhibit avoidance behaviors in more intensive verbal participation and they should communicate with the school guidance service, the family and other authorities in order to solve the problem, and cooperate at the solution point.

Another result of the study is that stuttering students have fewer problems in writing vocabulary, syllables and words than in their reading studies. According to the knowledge gained from the teacher's views, the stuttering students' achievement levels in the writing of sounds, syllables and words are not different from the other students in the class. This result shows that the stuttering students' academic performance in situations where there is no communication responsibility is not different from other children. When the literature is reviewed, there are researches supporting this result. Abli, Kınalı and Besikçi (2004) concluded that despite the difference between the Verbal IQ and the Performance IQ in the WISC-R test they applied to thirtyfive children aged six to eighteen years who were diagnosed with stuttering, this difference was not significant. According to Pamir's (1985) expression, stutterers are located within normal intelligence boundaries and intelligence point distribution is higher than other speech impairment groups. Pinarcik and Sar1 (2013) concluded that students with stuttering problems did not have a significant problem in academic and school achievement, but had problems in verbal lessons and activities.

When the research findings were carefully examined, it was concluded that stuttering students were partially challenged in their reading comprehension skills, but there was no significant difference between their peers in the class. However, according to the teacher's views, the result is that when students are confronted with a new text, when the reading is done aloud in the class, or because of the length of the words and sentences in the reading text, the intensity of stuttering increases and thus the reading comprehension skill varies. Starkweather (2002) concluded that the effect of the length of the sentence on the stuttering was significant. This result is similar to the result of the research. The main problem that stutterers face is about expressing the context which they understand. Instead of establishing a full sentence, students express it in one or two words, or they can develop some methods, 
such as using words that are not semantically equivalent to text when a word is difficult to say. The severity of stuttering and the impact of stuttering affect the classroom environment behaviors. He tells the class that he has not done his homework so that he does not have to read aloud, or he wants permission to leave the classroom because of the need for toiletries they are being asked to read. These behaviors, which are described as evasive behavior, characterize child behavior rather than stuttering.

Another result that emerged when the research findings were examined is that there is no significant difference between the stuttering student's transition to literacy and his or her peers. Stutter students; do not have any academic problems because of stuttering sounds, syllables and words, but they have problems with expressing what they have learned. It is seen that some of the teachers reported that students with stuttering were slightly delayed from other students to learn to read and write. Teachers, for their part, have shown that stuttering students do not participate in activities in the classroom. Another reason for the students not to participate in class activities is the negative attitudes and behaviors of their peers. Many stuttering children are exposed to negative behaviors such as ridicule, disdain; imitate speech and nickname by classmates. This situation causes the stuttering students to live psychological problems and affect their personality developments. As they are afraid of being exposed to negative attitudes and behaviors that can be described as peer bullying, they usually do not want to attend classes by complaints such as headache and stomachache. Prejudices and negative behaviors they are exposed increase the avoidance behavior of stuttering students. Prejudices and negative behaviors they are exposed increase the avoidance behavior of stuttering students. It is important for teachers to change attitudes towards stuttering students and to transform the classroom atmosphere into positive for stuttering students. If the teacher does not have any experience or training on stuttering, s/he has difficulty in helping the stuttering child. Many teachers feel helpless against this situation and do not know how to react in the case of stuttering. Especially in the crowded classroom environment, the workload makes it more difficult to acquire social and educational skills as well as to recognize stuttering students and to make them actively participate in class activities. 


\section{Conclusion and Suggestions}

The conclusions and suggestions arising from this research are presented in this section.

\section{Conclusion}

The results of the research are listed below.

1) In this study, it is found that students with stuttering did not have a significant difference in reading, writing and speaking vocabulary, syllables, and words in the first reading-writing process, and they were partially compelled to study voice, syllables and words.

2) Another result of the research is that the level of success of stuttering students in their writing, voice, syllable and words is not different from other students in the class. This result shows that the stuttering students' academic performance in situations where there is no communication responsibility is not different from other children.

3) When the research findings were examined, it was concluded that stuttering students were partially compromised in their reading comprehension skills, but there was no significant difference between their peers in the class. However, when the students were given a new text in a study of sequential reading aloud in the class, or the length of the words and phrases in the text being read increased the severity of the stuttering and thus the result of the reading understanding skills varied.

4) Another finding emerging from research findings is that there is no significant difference between the stuttering student's transition to literacy and the transition process of his or her peers. Stutter students do not have any academic problems because of stuttering; sounds, syllables and words, but they have problems with expressing what they have learned. It has been suggested that students with stuttering are a little late in learning to read and write than other students in the class. Stuttering students lagging in their literacy learning process is not because of academic inadequacy, but because of intense anxiety and lack of self-confidence that they have experienced because of stuttering. 


\section{Suggestions}

The following suggestions have been developed for the results of this research.

1. Teacher attitudes are very important in reducing the problems of academic and psycho-social development problems of students with stuttering. Seminars and conferences should be organized by Language and Speech Therapists under the auspices of the General Directorate of Special Education and Guidance Services to inform both guidance teachers and other teachers in their attitudes and approaches to stuttering students.

2. Students with stuttering problems can be provided with more active help from guidance counselors of the school in order to learn to cope with the psycho-social problems they face.

3. Peer education, which is assigned through teachers, may be included in order to increase the participation of students who have stuttering problems in class and out of class courses and other activities.

4. The teacher may make presentation to other students on stuttering in accordance with the approval of the stuttering student,

5. Organize discussions on differences in the classroom and enable students to gain a positive perspective on expressing opinions and ideas and respecting differences.

\section{Suggestions for further research;}

1. In this study, the teacher's opinions to identify the problems of stuttering students which they encountered during the learning of first literacy skills were examined. A new research can be designed by including students 'and parents' opinions.

\section{References}

Abalı, O.; Kınalı, G. ve Beşikçi, H. (2004). Kekemelik Bulunan Çocuk ve Gençlerde Kekemelik Şiddeti ile Zeka Gelişiminin Karşılaştırılması. Eskişehir: DİLKOM 2. Ulusal Dil ve Konuşma Bozuklukları Kongresi Bildiri Kitabı.

Anderson, J. D. and Conture, E. G. (2000). Language Abilities of Children who Stutter: A Preliminary Study. Journal of Fluency Disorders, 25 (4), 283-304. ISSN 0094730X. 
Andrews, G.; Craig; A.; Feyer, A.; Hoddinott; S.; Hoiwe, P. and Neilson, M. (1983). Stuttering: A Review of Research Findingsand Theories Circa 1982. The Journal of Speech and Hearing Disorders, 48 (3), 226-46. ISSN 0022-4677.

ASHA (American Speech-Language-Hearing Association). (2004). Terminology Pertainingto Fluency and Fluency Disorders: Guidelines. USA: American Speech-Language-Hearing Association.

Bakırcıoğlu, R. (2002). Çocuk Ruh Sağllğı ve Uyum Bozuklukları. Ankara: Anı Yayıncilık. ISBN 9756956656.

Baumgartner, S. (1997). Sprachflüssigkeit. In: Baumgartner, S. Füssenich, I. Sprachtherapie mit Kindern.Münschen/ Basel. ISBN 9783825287146.

Belgin, E. ; Derinsu, U. (1990) İlkokul Çağı Çocuklarında Konuşma ve Ses Bozukluğu İnsidans1, 19. Türk Milli Otorinolarengoloji Kongresi. İstanbul: Çertüt Matbaacıllk A.Ş.

Bernitzke,F. (2014). Heilund Sonderpedagogik. Köln: Bildungsverlag EINS. ISBN 9783823715429 .

Bloodstein, O. (1995), A Handbook on Stuttering. Fifth Edition. San Diego: Singular Publishing Group, Inc. ISBN 9781565933958.

Bloodstein, O. and Ratner, N. B. (2008). A Handbook on Stuttering. Thomson/Delmar Learning, Clifton Park, NY. ISBN 9781565933958.

Bryan, L.J. and Bryan, L.T. (1982) Exceptional Children. California: Mayfield Publishing Company.

Büchel, C. and Sommer, M. (2004). What Causes Stuttering? PLOS biology, 2 (2), 46. ISSN 1544-9173.

DSM-IV-TR (Diagnosticand Statistical Manual of MentalDisorders). (2005). Zeka Geriliği Tanılama ve İstatistik El Kitabı. (Çev. E. Köroğlu), Ankara: Hekimler Yayın Birliği.

Dreizehnter, P. (2009). Benachteiligung von der Stottern in der Schule. Weingarten: Diplomarbeit. HochschuleRawensburg

Fiedler, P., Standop, R. (1994). Stottern. Ätiologie, Diagnose, Behandlung. 4. Aufl. Weinheim: PVU.

Fışıloğlu, A.; Ungan, İ. (1992) 9-12 Yaş Arası Normal Konuşan Çocukların Kekemeliğin Değerlendirmesi. Psikoloji Dergisi,7:2-8. ISSN 2147-6489.

Guitar, B. (2006). Stuttering: An Integrated Approach to Its Nature and Treatment. Baltimore: Lippincott Williams and Wilkins. ISBN 9781608310043. 
İnceer, B. ; Kocadere, M. (1999). Kekemelik ve Kekelemek Üzerine. İzmir: Ege Üniversitesi Basımevi.

Hansen, B., Iven, C. (2002). Stottern und Sprechflüssigkeit. Münschen: Urban \& Fischer Verlag. ISBN 9783437473609.

Karacan, E. (2000). Çocuklarda Kekemelik ve Diğer İletişim Bozuklukları. Psikiyatri Dünyası, (4), 18-21. ISSN 1302-6631.

Kehoe, T. D. (1996), Stuttering: Science. Therapy and Practice. Boulder, CO: Thomas David Kehoe. ISBN 9780965718103.

Madanoğlu, K. G. (2005). Kekeme Çocuklar İçin Bir Tarama Çalışması ve Kekemelikle Baş Etme Konusunda Hazırlanmış Bir Programın Değerlendirilmesi. Yayımlanmamış Doktora Tezi. İstanbul: Marmara Üniversitesi Eğitim Bilimleri Enstitüsü. ISSN 1300-8757.

Manning, W.H. (2001). Clinical Decision-Making İn Fluency Disorders. Canada: SingularThomson Learning. ISBN 9781418067304.

Mavis, İ. (2005). Çocuklarda Dil ve Konuşma Bozuklukları ve Öğrenmeye Etkileri.İşitme, Konuşma ve Görme Sorunları Olan Çocukların Eğitimi. Ü. Tüfekçioğlu (Ed.). Eskişehir: Anadolu Üniversitesi Yayınları. ISBN 9786055885267.

Natke, U. (2005). Stottern: Erkenntnisse, Theorien, Behandlungsmethoden. 2. Aufl. Bern: Hans Huber. ISBN 9783456848914.

Onslow, M., Ross, M. and Pockman, A. (2001). An operant intervention for early stuttering. Behavior Modification, 21;116-240. ISSN 0145-4455.

Owens, R. E.; Metz, D. E. and Haas, A. (2003). Introduction to Communication Disorders: A Life Span Perspective. Boston: Allynand Bacon, (252), 263-266. ISBN 9780205487875.

Özsoy, Y. (1982). Konuşma Özürlü Çocuklar ve Eğitimleri. (2. Basım). Eskişehir: İ. T. İ. A. Yayınları, No: 4.

Özsoy, Y., Özyürek, M. ve Eripek, S. (1998). Özel Eğitime Giriş. Ankara: Karatepe Yayınları.

Öztürk, M. (1994) Çocukluk Çağı Ruhsal Sorunları ve Bozuklukları, Ruh Sağlığı ve Bozuklukları. O. Öztürk (ed.). 5. Baskı. Ankara: Medikomat Basım Yayın. ISBN 9789759345334.

Pamir, T. (1985). Kekemelik Tedavisinde Uyarlanan Geri Bildirim Tekniği ve 17 Denek Üzerindeki Sonuçları. Psikoloji Dergisi, (5), 24-30.

Perkins, W. H. (1990). What is Stuttering? Journal of Speech and Hearing Disorders, (55), 370-382. ISSN 0022-4677. 
Pınarcık, Ö. (2013). 6-8 Yaş Kekeme Öğrencilerin Psiko-Sosyal Ve Akademik Yönden Karşılaştıkları Güçlüklerin Öğrenci, Öğretmen, Veli Görüşleri Açısından Değerlendirilmesi. Yayınlanmış Doktora Tezi. Konya,Selçuk Üniversitesi Sosyal Bilimler Enstitüsü.

Pınarcık, Ö., Sarı, H. (2013). Tanım Açısından Kekemeliğe Yönelik Yeni Bulguların Değerlendirilmesi. Karaelmas Journal of Educational Sciences 1 (2013) 33-42. ISSN 1454-7678.

Sandrieser, P. ve Schneider, P. (2008). Stottern im Kindesalter. Stutgart: Georg Thieme Verlag. ISBN 9783131184542.

Sarı, H.,Gökdağ, H. (2017). An Analysis of Difficulties of Children with Stuttering Enrolled in Turkish Primary Inclusive Classes who Encounter in Academic and Social Activities: From Their Perspectives. Journal of Education and Practice Vol. 8, No.2, 2017. ISSN 2311-6897.

Shapiro, D. A. (1999). Stuttering Intervention. A Collaborative Journey to Fluency Freedom(Pro. Ed), (48), 61-81. ISBN 9780890797402.

Shipley, K. G. and McAfee, J. G. (2004). Assessment of Fluency. Assessment in Speech Language Pathology. (Esperti, C. L. Ed.), United States Of America: Thomson Delmar Learning. ISBN 9781418053284.

Starkweather, C. W. (1993). Issues in the efficacy of treatment for fluency disorders. Journal of Fluency Disorders, 18, 151-168. ISSN 0094-730X.

Starkweather, C. W. (2002). TheEpigenesis of Stuttering. Journal of Fluency Disorders, (27), 269-288. ISSN 0094-730X.

Tanner, D. C. (2003). Exploring Communication Disorders: A 21st Century Introduction Through Literature and Media. Boston: Allynand Bacon. ISBN 9780205373604.

Turan, A. (2016). Konuşma ve Dil Gelişimi Rehabilitasyonu, Down Sendromu, Otizm ve Kekemelik İçin Rehber Kitap.4. Baskı,İstanbul: Ege Yayınları. ISBN 9786059680004.

Türnüklü, A. (2000). Eğitimbilim Araştırmalarında Etkin Olarak Kullanılabilecek Nitel Bir Araştırma Tekniği: Görüşme. Kuram ve Uygulamada Eğitim Yönetimi, (24), 543-559. ISSN 1300-4832.

Van Riper, C. (1972). The Nature of Stuttering, New Jersey: Prentice Hall. ISBN 9780881336771.

Ward, D. (2006). Stuttering and Cluttering: Frameworks for Understanding and Treatment. Hove: Psychology Press. ISBN 9781841693347. 
Williams, C. (2004). Pragmatic and cross-cultural consideration sins translating verbal Constructions in Prescriptive Legal Texts in English and İtalian. Textus, 18; 217-245. ISSN 2589-255X.

Wingate, M. E. (2002). Foundations of Stuttering. San Diego: Academic Press, (31), 167-170.

Wischner, J. G. (1992). An Expectancy and Anxiety in Stuttering Behavior. Emerick, L. L, Hamre, L. E. (Ed.), An Analysis of Stuttering, 607-625, Danville: The Interstate Printersand Publishers, Inc.

Yairi, E. and Ambrose, N. G. (1993). The Early Months of Stuttering: A Developmental Study. Journal of Speech and Hearing Research,(36), 521-528. ISSN 1092-4388.

Yairi, E.;Ambrose, N. G. (2005a). Early Childhood Stuttering. (Pro.ed) Texas: An International Publisher.

Yaruss, J. S. (1999). Utterance Length, Syntactic Complexity and Childhood Stuttering. Journal of Speech Language and Hearing Research, (42), 329-344. ISSN 10924388 .

Yıldırım, A.; Şimşek, H. (2006). Nitel Araştırma Yöntemleri. Ankara: Seçkin Yayıncılık. ISBN 9750200071.

Yörükoğlu, A.; Akyıldız, S. (1971) 75 Çocukta Yeni Başlayan Kekemelik Üzerine Bir İnceleme, 7. Milli Nöro-psikiyatri Kongresi Bilimsel Çalışmaları, Ajans Türk Matbaac1lık Sanayi, 373-382 
